American Journal of Biochemistry and Biotechnology 4 (4): 425-430, 2008

ISSN 1553-3468

(C) 2008 Science Publications

\title{
Serotonergic Properties of the Roots of Clerodendron capitatum
}

\author{
${ }^{1}$ Siddig Ibrahim Abdel Wahab, ${ }^{2}$ Abdel Wahab Hassan Mohamed, ${ }^{3}$ Osama Yousif Mohamed, \\ ${ }^{1}$ Manal Mohamed Elhassan Taha, ${ }^{1}$ Ahmad Bustamam Abdul and ${ }^{1}$ Adel Sharaf Al-Zubairi \\ ${ }^{1}$ UPM-MAKNA Cancer Laborarty, Institute of Biosciences, \\ University Putra Malaysia, Kuala Lumpur, Malaysia \\ ${ }^{2}$ Medicinal and Aromatic Plants Institute, Khartoum, Sudan \\ ${ }^{3}$ Department of Pharmacology, \\ Faculty of Pharmacy, University of Khartoum, Khartoum, Sudan
}

\begin{abstract}
The aim of this study is to investigate the pharmacological effects of the methanolic extract of Clerodendron capitatum, CC, (family verbenaceae). These investigations were carried out on isolated frog rectus abdominus muscle and rabbit aortic strips and jejunum and non-pregnant rat uterus pretreated with oestradiol. Results showed that $\mathrm{CC}$ did not demonstrate any contracting, relaxant or blocking effects on frog rectus abdominus muscle and rat aortic strip preparations. The extract produced a concentration-dependent $(\mathrm{p}<0.05$, $\mathrm{t}$-test, $\mathrm{n}=6$ ) decrease of the normal rhythmic contraction of rabbit jejunum, however, this effect was reversed by prior addition of cyproheptadine (non-specific 5-HT antagonist). In addition, CC also produced a stimulant activity on rat uterus which was blocked by cyproheptadine. Future study is recommended to study the specificity of CC to different 5-HT receptors by using different isolated animal tissues and specific 5-HT antagonists.
\end{abstract}

Key words: Clerodendrum capitatum, adrenergic, cholinergic effects, 5-HT

\section{INTRODUCTION}

Plants have been used as a source of medicine throughout history and continue to serve as the basis for many pharmaceuticals used today. Plants carry on providing a valuable source of therapeutic compounds because of their enormous biosynthetic capacity ${ }^{[1,2]}$. A primary advantage of botanicals is their complex composition consisting of collections of related compounds having multiple activities that interact for a greater total activity ${ }^{[2-4]}$. Despite appreciable progress made in the managing of various diseases using the conventional therapeutic schemes, the search for plantbased products for the control of such diseases continues.

Clerodendrum capitatum (Willd) (family: verbenaceae), locally named "Gung" in Sudan, is an indigenous tropical African plant, which growing fast, erect, well branched, having perennial undershrub and grows up to $0.5-2 \mathrm{~m} \mathrm{high}^{[5]}$. Its stem is quadrangular in transverse section and it is covered with soft hair. The plant leaf is simple, oval or elliptical, generally bent at the base, rigid, leaving an under thorn stab on the stem after the fall of the leaf. Its inflorescence is glomerular with globular terminal auxillage and flowers yearly ${ }^{[5,6]}$. In Sudan, dried roots of this plant are used traditionally in the management of erectile dysfunction in male ${ }^{[6]}$. In Nigeria, The plant though reputed for bone healing in fractures and as such popularly called medicinalmagical plant ${ }^{[5]}$; it is equally reputed for local management of diabetes mellitus, obesity and hypertension.

The genus Clerodendron, is reported to demonstrate biological activities such as antitumorgenic ${ }^{[7,8]}$, Hypoglycemic, hypolipidemic ${ }^{[5,9]}$, Hepatoprotective activity against $\mathrm{CCl}_{4}$ induced liver injury in rats ${ }^{[10,11]}$, Anti-inflammatory ${ }^{[12-14]}$, free radicalscavenging activity, Anti-diarrhoeal, Antinociceptive and antipyretic effects ${ }^{[15-17]}$.

To the best of our knowledge, there is only one scientific report published regarding the phytomedicinal properties of CC by Adeneye et al. ${ }^{[6]}$. Therefore, an extensive pharmacological investigation is needed to explore the biological activities of this plant. We consequently, investigate the pharmacological properties of $\mathrm{CC}$ on isolated animals' organs to elucidate its aphrodisiac properties and contribute to the scientific literature of this plant. 


\section{MATERIALS AND METHODS}

Plant material and extraction of CC: The plant C. capitatum was collected by a team from Medicinal and Aromatic Plants Research Institute, National Center for Research (MAPRI, NCR, Sudan), from Nuba Mountains, Sudan. The plant was identified and authenticated by Dr. G.E.B. Elgazali, Department of Chemistry, Production and Classification, MAPRI, NCR. A voucher specimen was prepared and deposited in the Herbarium, MAPRI, NCR. The roots of the plant were air-dried in the shade and kept in clean container.

Preparation of the extract: The coarsely powdered roots $(300 \mathrm{~g})$ of the plant were exhaustively extracted with methanol in a soxhlet apparatus. The extract was then evaporated under reduced pressure and kept in a refrigerator for biological investigations. The percentage yield of the powdered roots of the plant was found to be $9.67 \%$ (the \% yield of the crude extracts was calculated as: Weight of crude extract/weight of dried plant X 100\%). On redissolving the extract in distilled water produced a brownish solution, which was added directly to the tested preparation.

Experimental animals: All experiments were performed in accordance with the "guiding principles for the care and use of laboratory animals" approved by the scientific committee for the experimental units, Medicinal and Aromatic Plants Research Institute, National Center for Research (MAPRI, NCR), Sudan.

Effects of $\mathrm{CC}$ on frog rectus abdomenus muscle: Frogs weighing 20-25 g were used in this study $(\mathrm{n}=6)$. The frog was stunned and decapitated and the spinal cord was destroyed. The two recti muscles were localized, running each side of the midline from the base of the sternum to the fork. Then, the pair of rectus abdominus muscle were dissected out and transferred to a petri-dish containing frog-ringer solution $(\mathrm{NaCl}, \mathrm{KCl}$, $\mathrm{NaH}_{2} \mathrm{PO}_{4} \cdot 2 \mathrm{H}_{2} \mathrm{O}$, Glucose, $\mathrm{NaHCO}_{3}$ and $\mathrm{CaCl}_{2}$ ) at ambient temperature. The muscle was mounted in a $25 \mathrm{~mL}$ organ bath filled with aerated Frog-Ringer solution and attached to Harvard isotonic transducer. The contractures of the muscle were recorded on Harvard Oscillographic recorder. The tissue was allowed to equilibrate under $0.5-1 \mathrm{~g}$ tension for $1 \mathrm{~h}$, before starting the administration of plant extract and acetylcholine, the standard drug.

Effects of CC on rabbit aortic strip: Rabbit of local strain $(1.5-2 \mathrm{Kg}, \mathrm{n}=6)$ were used. The rabbit was killed by neck dislocation and exsanguinated. Then the aorta was exposed and cut close to the heart. Aortic tissue was transferred to a petri dish containing aerated Kreb's solution $\left(\mathrm{NaCl}, \mathrm{KCl}, \mathrm{MgSO}_{4} .7 \mathrm{H}_{2} \mathrm{O}, \mathrm{KH}_{2} \mathrm{PO}_{4}\right.$, Glucose, $\mathrm{NaHCO}_{3}$ and $\mathrm{CaCl}_{2}$ ). The aorta was located over a plastic canulla and the surrounding fat and connective tissues were removed and it was cut spirally to produce continuous strip. A thread was tied to each end of the strip (3-4 cm) and one end was fixed to tissue holder. The preparation was transferred to $25 \mathrm{~mL}$ organ bath filled with aerated Kreb's solution maintained at $37^{\circ} \mathrm{C}$. The isometric contractions were recorded using Harvard isometric transducer connected to Harvard oscillographic recorder. The preparation was allowed to equilibrate under $1.5-2 \mathrm{~g}$ tension for at least $45 \mathrm{~min}$. Plant extract was left in tissue contact for $2 \mathrm{~min}$.

Effects of CC on Rabbit Jejunum: For this experiment, about $2-3 \mathrm{~cm}$ of jejunum tissue were taken out and placed in a petri-dish containing Tyrode solution $\left(\mathrm{NaCl}, \mathrm{KCl}, \mathrm{MgSO}_{4} \cdot 7 \mathrm{H}_{2} \mathrm{O}, \mathrm{NaH}_{2} \mathrm{PO}_{4} \cdot 2 \mathrm{H}_{2} \mathrm{O}\right.$, Glucose, $\mathrm{NaHCO}_{3}$ and $\mathrm{CaCl}_{2}$ ) at room temperature. The preparation was freed from fats and connective tissues and transferred to an organ bath $(25 \mathrm{~mL})$ containing aerated tyrode solution maintained at $37^{\circ} \mathrm{C}$. The tissue was allowed to settle for at least $45 \mathrm{~min}$. The responses to drugs and plant extract were recorded using isotoinc transducer connected to the recorder, under $0.5 \mathrm{~g}$ tension. Plant extract was left in tissue contact for $3 \mathrm{~min}$ $(\mathrm{n}=6)$.

Rat uterus preparation: Female young non-pregnant Wister rats, weighing 120-150 gm were used in this study. To increase the sensitivity of uterine tissue, animal were brought into oestrus by subcutaneous administration of $\beta$-estradiol-3-benzoate $\left(2.5 \mathrm{mg} \mathrm{kg}^{-1}\right)$ $40 \mathrm{~h}$ prior to the experiment. Preparation of the uterus was carried out according to the method described by ${ }^{[18]}$. The rat was killed by a blow on the head and exsanguinated. The abdomen was opened and the two uterine horns were exposed by pulling aside the intestine. Each horn was freed carefully from surrounding fat and mesenteric attachments, cut out separately and transferred to a petri-dish containing De Jalon's solution $\left(\mathrm{NaCl}, \mathrm{KCl}\right.$, Glucose, $\mathrm{NaHCO}_{3}$ and $\mathrm{CaCl}_{2}$ ). Each horn was cut open longitudinally to form a sheet of muscle instead of a narrow tube. A thread was attached at each end of piece and the preparation was mounted in a $25 \mathrm{~mL}$ organ bath containing aerated De Jalon's solution maintained at $37^{\circ} \mathrm{C}$ with one attached to a fixed pin and the other to an isometric transducer (Harvard) connected to Harvard oscillographic recorder. The preparation was allowed to 
equilibrate for $45 \mathrm{~min}$, under 0.5 tension before addition of the plant extract and the reference drugs.

Statistical analysis: All experimental data was expressed as mean \pm SD. Student's t-test was used to analyze the difference between the length of contracture of stimulated and un-stimulated intestinal tissues with 0.05 as a level of significance.

\section{RESULTS AND DISCUSSION}

The effect of CC roots methanolic extract on frog rectus abdominus muscle preparation is demonstrated in Fig. 1. The muscle was stimulated using acetylcholine in a dose of $1 \mu \mathrm{g} \mathrm{mL}^{-1}$ gut-bath, to produce a reference contraction and to study the blocking effect of the extract. Frog skeletal muscle reached the maximum contracture in 2 min upon the administration of Ach. The plant methanolic extract in a dose of 2 and $4 \mathrm{mg} \mathrm{mL} \mathrm{m}^{-1}$ gut-bath, when added to the tissue and left for 2 min for each dose, did not produce cholinergic effect and fail to block acetylcholine. As depicted in Fig. 2, extract of CC in a dose of 2 and $4 \mathrm{mg} \mathrm{mL}^{-1}$ gutbath did not produce any pharmacological activities on rabbit aortic strip preparation. Adrenaline achieved the maximal contracture in 2 min time when added in a dose of $2 \mathrm{mg} \mathrm{mL}^{-1}$ gut-bath. In the presence of CC extract at dose of $4 \mathrm{mg} \mathrm{mL}^{-1}$ gut-bath, adrenaline was not blocked by the extract $(n=6)$.

Isolated rabbit jejunum was treated by plant methonlic extract in a dose of 2 and $4 \mathrm{mg} \mathrm{mL}^{-1}$ gut-bath.

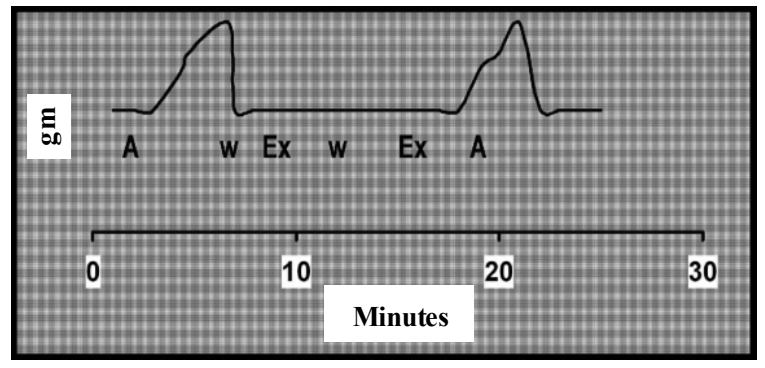

Fig. 1: Effect of $\mathrm{CC}$ roots methanolic extract (Ex) on frog rectus abdominus muscle preparation. Acetylcholine (A) was administered to achieve standard peak of contracture. The extract was added in a dose of 2 and $4 \mathrm{mg} \mathrm{mL}^{-1} 25 \mathrm{~mL}$-gutbath). With prior existence of the extract in a dose of $4 \mathrm{mg} \mathrm{mL}^{-1}$, acetylcholine achieved the same contracture. W: A flushing using physiological solution (Frog-Ringer) was performed after each step
This dose has induced decreasing in the length of contracture (Table 1). The extract exerted maximal response in $2 \mathrm{~min}$. The stimulant effect of $\mathrm{CC}$ on rabbit jejunum was reversed by prior addition of cyproheptadine ( $2 \mu \mathrm{g} \mathrm{mL}^{-1}$ gut-bath). The effect of CC on rabbit isolated intestine is noticed to be dose dependent $(\mathrm{p}<0.05$, t-test, $\mathrm{n}=6)$. The Contracting effects of $\mathrm{CC}$ on rat uterus preparation are shown in Fig. 3. Rat's treatment with oestradiol $\left(0.25 \mathrm{mg} \mathrm{mL}^{-1}\right)$ increased the sensitivity of uterine muscle towards the extract.

Addition of the extract in of $2 \mathrm{mg} \mathrm{mL}^{-1}$ (gut-bath) elicited rapidly developing contraction on rat uterus which attained maximum in $2 \mathrm{~min}$. This stimulant effect of CC extract on rat uterus was blocked by prior addition of cyproheptadine (5-HT non-selective antagonist) in a dose of $2 \mu \mathrm{mg} \mathrm{mL} L^{-1}$.

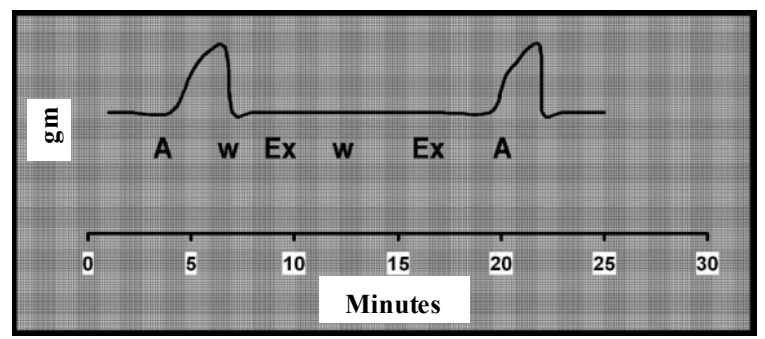

Fig. 2: Influence of methanolic extract of $\mathrm{CC}$ on rabbit aortic strip (Ex). Adrenaline in a dose of $2 \mu \mathrm{g}$ $\mathrm{mL}^{-1}$ was administered to produce standard contractile peak. Plant extract was added in a dose of 2 and $4 \mathrm{mg} \mathrm{mL}^{-1}$. Adrenaline also was added extract administration $\left(4 \mathrm{mg} \mathrm{mL}^{-1}\right)$ to investigate the blocking effect of the extract. W: flushing using physiological solution (Kreb's Solution) was performed after each step

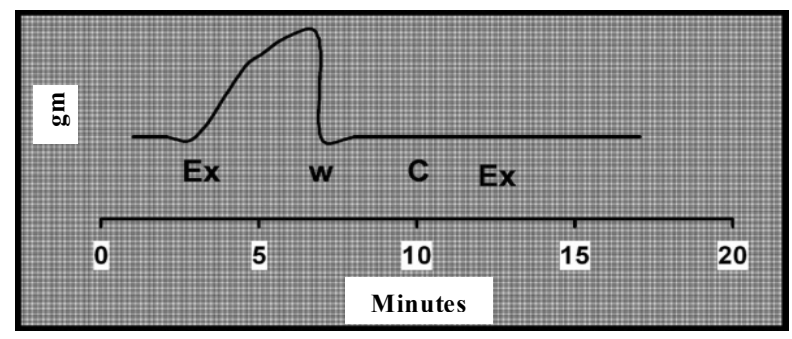

Fig. 3: Administration of CC extract (Ex) on uterus of oestradiul pretreated rats. The extract revealed serotonergic effect in a dose of $2 \mathrm{mg} \mathrm{mL}^{-1}$. The effect was reversed by the non-selective 5-HT antagonist, Cyproheptadine (C). W: Flushing using physiological solution (Kreb's Solution) was performed after each step 
Table 1: Rabbit isolated jejunum responses to the administration of the methanolic extract. The extract in a dose of 2 and $4 \mathrm{mg}$ $\mathrm{mL}^{-1}$ stimulated the intestine in a dose dependentmanner $(\mathrm{p}<0.05$, $\mathrm{t}$-test); the effect was reversed by prioraddition of cyproheptadine (serotonin antagonist) in adose of $2 \mu \mathrm{g} \mathrm{mL}^{-1}$ Percentage of decreasing in the length of contracture

\begin{tabular}{lll}
\hline $4 \mathrm{mg} \mathrm{mL}^{-1}$ & $2 \mathrm{mg} \mathrm{mL}^{-1}$ & $4 \mathrm{mg} \mathrm{mL}^{-1}+$ Cyproheptadine \\
$56.2 \pm 6.7$ & $23.2 \pm 3.9$ & $3.7 \pm 3.4$
\end{tabular}

Herbal preparations are widely accepted and used in the population. The pharmacological characterization of such products meets some specific challenges ${ }^{[19,20]}$. The powdered roots of $\mathrm{CC}$, which is used in Sudanese folk medicine for the treatment of male impotence, is pharmacologically investigated. Therefore, the aim of the present study was to determine if the methanolic extract of the roots of $\mathrm{CC}$ has a pharmacological effect on rabbit isolated jejunum and aorta, frog rectus abdominus muscle and rat uterus for its blocking, contracting or relaxant effects on animal's tissue preparations. The effects of the methanolic extract on isolated animal tissues were studied, using well-characterized assays for pharmacological studies.

The results obtained in this study, indicate that the methanolic extract of $\mathrm{CC}$ roots does not produce blocking effect since it fails to antagonize the stimulant effect of adrenaline, an adrenergic agonist ${ }^{[21]}$, on isolated rabbit aortic strips. In addition, the extract did not show any pharmacological activities on frog rectus abdominus muscles, whereby, no contraction, relaxation or blocking properties towards acetylcholine induced contraction of the skeletal muscle were observed. It could be concluded that, the methanolic extract of $\mathrm{CC}$ revealed no pharmacological activity (Cholinergic and adrenergic agonism and antagonism) on both skeletal and smooth muscle of frog and rat, respectively.

The extract was also applied in the tissue preparation of rabbit jejunum and the response was recorded using Harvard Oscillographic recorder. Interestingly, the contracture length of intestinal smooth muscle was reduced in a concentration dependent manner $(\mathrm{p}<0.05$, t-test) upon the addition of $\mathrm{CC}$ in a dose of 2 and $4 \mathrm{mg} \mathrm{mL}^{-1}$ (gut-bath); however, this effect was reversed by prior addition of cyproheptadine (non-specific serotonin antagonist) in a dose of $2 \mu \mathrm{g} \mathrm{mL}{ }^{-1}$. Recent studies have demonstrated that serotonin (5-hydroxytryptamine, 5-HT) may interact with either specific receptors or with a specific transporter that takes up 5-HT in the gastrointestinal tract ${ }^{[22]}$. These serotonergic properties of $\mathrm{CC}$ further confirmed that $\mathrm{CC}$ did not produce its stimulant effect on intestinal smooth muscles through any action on adrenergic receptors.
In addition, the serotonergic properties of $\mathrm{CC}$ on 5-HT receptor (s) was further investigated, whereby, $\mathrm{CC}$ was administered on uteri preparation from female rats pretreated $(24 \mathrm{~h})$ with oestradiol. The results obtained from this experiment have indicated the possession of $\mathrm{CC}$ to serotonergic properties that could be reversed by prior addition of cyproheptadine. However, it has been postulated that the majority of the contractile response to 5-HT in rat aorta is mediated by 5-HT2 receptors ${ }^{[23,24]}$. There are two functional 5-HT receptors in rat aorta: 5 -HT $(2 \mathrm{~A})$ contractile receptor in smooth muscle and a high-affinity relaxant receptor that mediates a very slight response and the pharmacology of which could be compatible with an endothelial 5-HT (2B) receptor ${ }^{[25]}$. On the other hand, 5-HT receptormediated contractile responses of $\mathrm{CC}$ on rabbit jejunum might be due to the occupation 5-HT4 receptors because the 5-HT2 or 5-HT3 receptors are not present in the small intestine ${ }^{[26]}$. With regards to the results of the present study, a deeper investigations are needed to locate the subtype of 5-HT that is responsible to interact with CC.

\section{CONCLUSION}

In conclusion, the methanoloic extract of the roots of $C$. capitatum has not produced any contracting, relaxant or blocking effects on frog rectus abdominus muscle and rat aortic strip preparations. But this plant has shown 5-hydroxytryptamine like activity on rabbit small intestine and rat uterus which is reversed by cyproheptadine. This serotonergic activity needs more investigations to specify the 5-HT receptors that are capable to interact with the methanoloic extract of the roots of $C$. capitatum.

\section{ACKNOWLEDGEMENT}

We are very grateful to Mr. Mahjoub Oall who provided great facilities on extraction and the cooperative support from the staff in the Laboratory of Pharmacology and Toxicology, MAPRI, NCR.

\section{REFERENCES}

1. Itokawa, H., S.L. Morris-Natschke, T. Akiyama and K.H. Lee, 2008. Plant-derived natural product research aimed at new drug discovery. Nat. Med., 62: 263-280. DOI: 10.1007/s1 1418-008-0246-z.

2. Schmidt, B., D.M. Ribnicky, A. Poulev, S. Logendra, W.T. Cefalu and I. Raskin, 2008. A natural history of botanical therapeutics. Metabolism, 57: S3-S9. http://www.ncbi.nlm.nih.gov/pubmed/18555851. 
3. Balunas, M.J. and A.D. Kinghorn, 2005. Drug discovery from medicinal plants. Life Sci., 78: 431-441. DOI: 10.1016/j.lfs.2005.09.012.

4. Lee, K.H., 1999. Novel antitumor agents from higher plants. Med. Res. Rev., 19: 569-596. http://www.ncbi.nlm.nih.gov/pubmed/10557371.

5. Adeneye, A.A., T.I. Adeleke and A.K. Adeneye, 2008. Hypoglycemic and hypolipidemic effects of the aqueous fresh leaves extract of Clerodendrum capitatum in Wistar rats. J. Ethnopharmacol., 116: 7-10. DOI: 10.1016/j.jep.2007.10.029.

6. Mahmoud, A., M.O. Khidir, M.A. Khalifa, A.B. El Ahmadi, H.A. Musnad and E.I. Mohamed, 1995. Sudan: Country Report to the Fao International Technical Conference on Plant Genetic Resources, pp: 67. http://www.fao.org/ag/AGP/agps/PGRFA/pdf/suda n.pdf.

7. Manoharan, S., K. Kavitha, N. Senthil and G.L. Renju, 2006. Evaluation of anticarcinogenic effects of Clerodendron inerme on 7, 12-dimethylbenz (a) anthracene-induced hamster buccal pouch carcinogenesis. Singapore Med. J., 47: 1038-1043. http://www.ncbi.nlm.nih.gov/sites/entrez/17139399.

8. Liu, S., H. Zhu, S. Zhang, X. Zhang, Q. Yu and L. Xuan, 2008. Abietane diterpenoids from Clerodendrum bungei. J. Nat. Prod., 71: 755-759. http://www.ncbi.nlm.nih.gov/pubmed/18348535.

9. Devi, R. and D.K. Sharma, 2004. Hypolipidemic effect of different extracts of clerodendron colebrookianum walp in normal and high-fat diet fed rats. J. Ethnopharmacol., 90: 63-68. http://www.ncbi.nlm.nih.gov/pubmed/14698510.

10. Vidya, S., V. Krishna, B.K. Manjunatha, K.L. Mankani, N. Ahmed and S.D. Singh, 2007. Evaluation of hepatoprotective activity of Clerodendrum serratum L. Indian J. Exp. Biol., 45: 538-542. http://www.ncbi.nlm.nih.gov/pubmed/17585689.

11. Gopal, N. and S. Sengottuvelu, 2008. Hepatoprotective activity of Clerodendrum inerme against $\mathrm{CCL}_{4}$ induced hepatic injury in rats. Fitoterapia, 79 24-26. http://www.ncbi.nlm.nih.gov/pubmed/17904308.

12. Narayanan, N., P. Thirugnanasambantham, S. Viswanathan, V. Vijayasekaran and E. Sukumar, 1999. Antinociceptive, anti-inflammatory and antipyretic effects of ethanol extract of Clerodendron serratum roots in experimental animals. J. Ethnopharmacol., 65: 237-241. http://www.ncbi.nlm.nih.gov/pubmed/10404422.
13. Panthong, A., D. Kanjanapothi, T. Taesotikul, T. Wongcome and V. Reutrakul, 2003. Antiinflammatory and antipyretic properties of Clerodendrum petasites S. Moore. J. Ethnopharmacol., $\quad$ 85: 151-156. http://www.ncbi.nlm.nih.gov/pubmed/12576214.

14. Choi, J.H., W.K. Whang and H.J. Kim, 2004. Studies on the anti-inflammatory effects of Clerodendron trichotomum Thunberg leaves. Arch. Pharm. $\quad$ Res., 27: 189-193. http://www.ncbi.nlm.nih.gov/pubmed/15022721.

15. Chae, S., K.A. Kang, J.S. Kim, J.W. Hyun and S.S. Kang, 2006. Trichotomoside: A new antioxidative phenylpropanoid glycoside from Clerodendron trichotomum. Chem. Biodivers., 3: $\quad$ 41-48. http://www.ncbi.nlm.nih.gov/pubmed/17193214.

16. Chae, S., J.S. Kim, K.A. Kang, H.D. Bu, Y. Lee, Y.R. Seo, J.W. Hyun and S.S. Kang, 2005. Antioxidant activity of isoacteoside from Clerodendron trichotomum. J. Toxicol. Environ. Health A., 68: 389-400. http://www.ncbi.nlm.nih.gov/pubmed/15799629.

17. Rani, S., N. Ahamed, S. Rajaram, R. Saluja, S. Thenmozhi and T. Murugesan, 1999. Antidiarrhoeal evaluation of Clerodendrum phlomidis Linn. leaf extract in rats. J. Ethnopharmacol., 68: 315-319. http://www.ncbi.nlm.nih.gov/pubmed/10624894.

18. Vane, J.R. and K. William, 1973. The contribution of prostaglandins to contraction of the isolated uterus of the rat. Br. J. Pharmacol., 48: 629-639. http://www.ncbi.nlm.nih.gov/sites/entrez/.

19. Hamburger, M., 2007. New approaches in analyzing the pharmacological properties of herbal extracts. Proc. West Pharmacol. Soc., 50: 156-161. PMID: 18605255.

20. Shan, J.J., K. Rodgers, C.T. Lai and S.K. Sutherland, 2007. Challenges in natural health product research: The importance of standardization. Proc. West Pharmacol. Soc., 50: 24-30. http://www.ncbi.nlm.nih.gov/pubmed/18605225.

21. Pupo, A.S., D.L. Cavenaghi, M. Campos, M.P. Lucena, N.H. Jurkiewicz and A. Jurkiewicz, 1999. Effects of indoramin in rat vas deferens and aorta: Concomitant alpha1-adrenoceptor and neuronal uptake blockade. Br. J. Pharmacol., 127: 1832-1836. http://www.ncbi.nlm.nih.gov/pubmed/10482913.

22. Ana, I., S. Víctor, R. Jesús and L. Angeles, 2000. Study of serotonin interactions with brush border membrane of rabbit jejunum enterocytes. Eur. J. Pharmacol., 403: 9-15. http://www.ncbi.nlm.nih.gov/pubmed/10969138. 
23. James, G.M., W.C. Hodgson, E.A. Davis and J.M. Haynes, $1994 . \quad$ Attenuated 5hydroxytryptamine receptor-mediated responses in aortae from streptozotocin-induced diabetic rats. Br. Pharmacol., 111: 370-376. http://www.ncbi.nlm.nih.gov/pubmed/8012721.

24. Nishimura, Y. and A. Suzuki, 1995. Enhanced contractile responses mediated by different 5-HT receptor subtypes in basilar arteries, superior mesenteric arteries and thoracic aortas from strokeprone spontaneously hypertensive rats. Clin. Exp. Pharmacol. Physiol. Suppl., 22: S99-S101. http://www.ncbi.nlm.nih.gov/pubmed/9072460.
25. Villazón, M., J.F. Padín, M.I. Cadavid, M.J. Enguix, H. Tristán, F. Orallo and M.I. Loza, 2002. Functional characterization of serotonin receptors in rat isolated aorta. Biol. Pharm. Bull., 25: 584-590. http://www.ncbi.nlm.nih.gov/pubmed/12033497.

26. Katayama, K.I., K. Asano, K. Hag and T. Fukuda, 1997. High affinity binding of azasetron hydrochloride to 5-hydroxytryptamine receptors in the small intestine of rats. Jap. J. Pharmacol., 73: 357-360. http://www.ncbi.nlm.nih.gov/pubmed/9165374. 